\title{
Effects of Boiling Time on the Antioxidant Activity of Moringa Leaf Extract
}

\author{
Obiajulu, Emmanuel Ifeanyi ${ }^{1 *}$, Asogwa, Ifeyinwa Sabina ${ }^{2}$

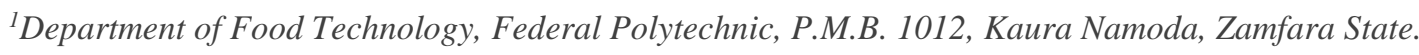 \\ ${ }^{2}$ Department of Food Science and Technology, University of Nigeria, Nsukka, Enugu State.
}

*Corresponding Author: Obiajulu, Emmanuel Ifeanyi, Department of Food Technology, Federal Polytechnic, P.M.B. 1012, Kaura Namoda, Zamfara State

\begin{abstract}
The effect of boiling time on the antioxidant activity of Moringa leaf extracts was determined by producing an aqueous extracts from Moringa oleifera leaves which was harvested, sorted weighed, washed and properly homogenized with distilled water using blender, the extracts were divided into segments; which are unboiled, boiled for five, ten and fifteen minute. The antioxidant activity of the extracts were determined using 2,2 Diphenyl-1-picrylhydrazyl (DPPH) and Ferric reducing antioxidant power (FRAP) methods at four different concentrations $(4,6,8$ and $10 \mathrm{mg} / \mathrm{ml})$; the DPPH and the FRAP value increased significantly with increase in both the boiling time and reagent concentration The nutritional composition, moisture was $84.915 \%$ for MLE15to $97.580 \%$ for MLEO, protein was $0.630 \%$ for MLEO to $1.395 \%$ for MLE15, fat $0.835 \%$ for MLEO to $2.955 \%$ for MLE15, for fibre nothing was detected for all the samples, carbohydrate $0.470 \%$ for MLEO to $9.280 \%$ for MLE15, the $\beta$-carotene was $1.447 \mathrm{mg} / 100 \mathrm{~g}$ for MLEO to $10.346 \%$ for MLE15 and vitamin C $20.850 \%$ for MLE15 to $32.970 \%$ for MLEO. All the data are expressed in mean of duplicate values and were subjected to ANOVA using SPSS version 16 at $p<0.05$.
\end{abstract}

Keywords: moringa, antioxidant, phytochemical, extracts, leaf, beta-carotene, vitamins.

\section{INTRODUCTION}

Africa is blessed with a sufficient array of phytochemical rich plant resources; unfortunately many are underutilized thereby limiting their health promoting benefits. Moringa is one of such underutilized crops, in order to promote its utilization and consumptions, studies aimed at investigating its antioxidant activity are pertinent.

Moringa oleifera is the most widely cultivated species in the genus Moringa, the only genus in the plant family Moringaceae. Common names include moringa, Drumstick tree, Ben oil tree or Benzoil tree [1] and it is also called "Zogale" in Northern Nigeria.

M. oleifera is a fast-growing, drought-resistant tree, native to the southern foothills of the Himalayas in Northwestern India, and widely cultivated in tropical and subtropical areas where its young seed pods and leaves are used as vegetables, and many parts of the tree are used in traditional herbal medicine. Moringa can also be used for water purification and hand washing [2]. The leaves are the most nutritious part of the plant, being a significant source of B vitamins, vitamin C, pro vitamin A as beta-carotene, vitamin $\mathrm{K}$, manganese, and protein, among other essential nutrients [3]. The leaves are cooked and used like spinach and are commonly dried and crushed into powder used in soups and sauces. [1].

Moringa oleifera are grown and used in many countries around the world is a multi-purpose tree with medicinal, nutritional and socio-economic values. In Senegal and Benin, M. oleifera leaves are dispensed as powder at health facilities to treat moderate malnutrition in children, which establishes the medicinal uses of $M$. oleifera leaves by local communities in Uganda. More than twenty-four medicinal uses of $M$. oleifera leaves were established and the medicinal abilities were as a result of the phytochemicals found in them. The local communities in Uganda use M. oleifera leaves to treat common ailments. Presence of phytochemicals in the extracts, indicate possible preventive and curative property of $M$. oleifera leaves [4]. 
Antioxidants are compounds that inhibit oxidation, oxidation is a chemical reaction that can produce free radicals, thereby leading to chain reactions that may damage the cells of organisms. Antioxidants such as thiols or ascorbic acid (vitamin C) terminate these chain reactions to balance the oxidative state, plants and animals maintain complex systems of overlapping antioxidants, such as glutathione and enzymes (e.g., catalase and superoxide dismutase), produced internally, or the dietary antioxidants vitamin $\mathrm{C}$, and vitamin $\mathrm{E}$ [5].

The term "antioxidant" is mostly used for two entirely different groups of substances: industrial chemicals that are added to products to prevent oxidation, and naturally occurring compounds that are present in foods and tissue. The former, industrial antioxidants have diverse uses: acting as preservatives in food and cosmetics, and being oxidation-inhibitors in fuels [5].

Antioxidants are the molecules that prevent cellular damage caused by oxidation of other molecules. Oxidation is a chemical reaction that transfers electrons from one molecule to an oxidizing agent which is known to produce free radicals. These free radicals are highly reactive species which contains one or more unpaired electrons in their outermost shell. Once they are formed, the chain reaction starts. Antioxidant reacts with these free radicals and terminates this chain reaction by removing free radical intermediates and inhibits other oxidation reactions by oxidizing themselves.

Although oxidation reactions are crucial for life, they can also be damaging, plants and animals have a complex system of multiple types of antioxidants, such as vitamin $\mathrm{C}$ and vitamin $\mathrm{E}$, as well as enzymes, such as catalase (CAT), superoxide dismutase (SOD), and various peroxidases [6]. Oxidative stress plays a key role in causing various human diseases, such as cellular necrosis, cardiovascular disease, cancer, neurological disorder, Parkinson's dementia, Alzheimer's disease, inflammatory disease, muscular dystrophy, liver disorder, and even aging. Besides, there are some antioxidants in the form of micronutrients which cannot be manufactured by the body itself such as vitamin $\mathrm{E}, \beta$-carotene, and vitamin $\mathrm{C}$, and hence these must be supplemented in the normal diet [7], and some of which can be affected by processing.

Food processing is the transformation of agricultural products into food, or of one form of food into other forms. Food processing includes many forms of treating foods, from grinding grain to make raw flour to home cooking to complex industrial methods used to make convenience foods [8]. It is known that processing affects the nutritional and phytochemical composition of plants.

\section{MATERIALS AND METHODS}

Fresh Moringa leaves were harvested from a farm in Eha-Alumona, Nsukka Local Government, Enugu State. Other chemicals and equipment used were from the Department of Nutrition and Dietetics Laboratory of the University of Nigeria Nsukka

\subsection{Preparation of the Aqueous moringa Leave Extracts}

Moringa leaf $(1.2 \mathrm{~kg})$ was used for the experiment, the leaves was divided into four (4) different treatment groups of $300 \mathrm{~g}$ each; unboiled, boiled for $5 \mathrm{mins}$, 10mins and $15 \mathrm{mins}$ respectively. An aqueous extraction was done on the individual groups by homogenizing the leaves with 1.2 ltrs of water in a blender (Binatone, Germany 8219sp) followed by filtration with muslin cloth then boiling at varying length of time as stated before for use. The samples were stored in separate dark coloured bottles, allowed to cool and later used for analysis.

\subsection{Proximate Analysis}

The following proximate analysis was determined, the moisture, ash, protein, fibre and carbohydrate contents of the leaf extracts.

\subsection{Determination of Moisture Content}

The moisture content of the samples was determined using the hot oven method of AOAC [9]. Exactly $5 \mathrm{ml}$ of each sample was put into a washed, dried and pre-weighed crucible dish and placed in a Phoenix oven at a temperature of $70-80^{\circ} \mathrm{C}$ for $2 \mathrm{hrs}$ and at $100-105^{\circ} \mathrm{C}$ until the weight was constant. The samples were cooled in desiccators and weighed. The weight loss was obtained as the moisture content and was calculated as:

$$
\% \text { Moisture content }=\frac{\mathrm{W}_{2}-\mathrm{W}_{3} \mathrm{X}}{\mathrm{W}_{2}-\mathrm{W}_{1}} 100
$$


Where; $\mathrm{W}_{1}=$ initial weight of empty crucible, $\mathrm{W}_{2}=$ weight of crucible + sample before drying

$\mathrm{W}_{3}$ = final weight of crucible + sample after drying

\subsection{Determination of Crude Protein}

The crude protein of the samples was determined by the semi-micro Kjeldahl technique described by AOAC [9]. Exactly $2 \mathrm{ml}$ of the sample was put into a Kjeldahl flask. Three grams ( $3 \mathrm{~g})$ anhydrous sodium sulphate and one $(1 \mathrm{~g})$ of hydrated copper sulphate (catalyst) were added into the flask. Then $20 \mathrm{ml}$ of concentrated tetraoxosulphate (VI) acid (H2SO4) was added to digest the sample.

The digestion continued under heat until a clear solution was observed. The clear solution was then cooled and made up to $100 \mathrm{ml}$ with distilled water and a digest of about $5 \mathrm{ml}$ was collected for distillation. Then $5 \mathrm{ml}$ of $60 \%$ sodium hydroxide $(\mathrm{NaOH})$ was put into the distillation flask and distillation was allowed to take place for some minutes. The ammonia distilled off was absorbed by boric acid indicator and this was titrated with $0.01 \mathrm{M}$ hydrochloric acid $(\mathrm{HCl})$. The titre value of the end point at which the colour changed from green to pink was taken. The crude protein was calculated as:

$\%$ Crude protein $=0.0001401 \times \mathrm{T} \times 100 \times 6.25$

$$
\mathrm{W} \times 5
$$

Where; $\mathrm{T}=$ titre value, $\mathrm{W}=$ weight of sample dried

\subsection{Determination of Fat Content}

The Soxhlet extraction method as described by AOAC [9] was used. The extraction flasks were washed with petroleum ether, dried and cooled and weighed. Two (2) $\mathrm{ml}$ of the samples were collected into the extraction thimble. It was then placed back in the Soxhlet apparatus. The washed flask was filled to about three quarter of its volume with petroleum ether (that has the boiling temperature range of 40-60 oC). The apparatus was then set-up and extraction carried out for a period of 4-6 hours after which complete extraction was made. The petroleum ether was recovered leaving only oil in the flask at the end of the extraction. The oil in the extraction flask was dried in the oven, cooled and finally weighed. The fat content was expressed as a percentage of raw materials. The difference in weight of empty flasks and the flask with oil content which was calculated as:

$\%$ Fat content $=\mathrm{C}-\mathrm{B} \quad \mathrm{X} 100$

$$
\text { A }
$$

Where B = Weight of empty flask, $\mathrm{A}=$ Weight of sample, $\mathrm{C}=$ Weight of flask + Oil.

\subsection{Determination of Crude Fibre}

The crude fibre content of the samples was determined using the method described by AOAC. [9]. Ten (10) $\mathrm{ml}$ of sample was digested with $200 \mathrm{ml}$ of $0.22 \mathrm{M} \mathrm{H} 2 \mathrm{SO} 4$, filtered and washed severally with quantitatively into another conical flask and dissolved in a $200 \mathrm{ml}$ of $1.25 \% \mathrm{NaOH}$ solution, boiled for 30 mins, cooled filtered and washed with boiling water.

The residue will be dried at $105 \mathrm{oC}$ for $2 \mathrm{hrs}$, cooled in a desiccators and weighed (W1).W1 will be incinerated at $550 \mathrm{oC}$ for $2 \mathrm{hrs}$ in a muffle furnace, cooled in a desiccators and reweighed (W2). Percentage crude fibre will be calculated thus:

(W1-W2/ S) X 100

Where: W1=weight of sample before incineration, W2 = weight of sample after incineration,

$\mathrm{S}=$ weight of sample use.

\subsection{Determination of Ash Content}

The ash content of the sample was determined by the method recommended by AOAC [9]. A silica dish was heated to about $60 \mathrm{oC}$, cooled in desiccators and weighed. $5 \mathrm{ml}$ of the sample was put into the silica dish and transferred to the furnace. The temperature of the furnace was then allowed to reach about $525 \mathrm{oC}$ after placing the dish in it. The temperature was maintained until whitish-grey colour was obtained indicating that all the organic matter content of the sample has been destroyed. The dish 
was then brought out from the furnace and cooled in the desiccators and re-weighed. The percentage ash content was the calculated as:

$\%$ ash content $=(\mathrm{C}-\mathrm{A} / \mathrm{B}) \times 100$

Where; $\mathrm{A}=$ weight of empty dish, $\mathrm{B}=$ weight of empty dish + sample before ashing

$\mathrm{C}=$ weight dish + ash

\subsection{Determination of Carbohydrate}

Carbohydrate was determined as the nitrogen free extraction calculated by difference as described by [9]. The formula below was used:

$\%$ Carbohydrate $=100 \%$ - (protein + fat + fibre + ash + moisture $)$

\subsection{Determination of Some Selected Vitamins}

Bearing in mind the food sample used for this experiment is a vegetable it was necessary to determine some predominant vitamins that are present in it and to also study the effect of boiling time to their availability to the consumers. Some of the determined vitamins where B-carotene (Vitamin A precusor) and Vitamin C.

\subsection{Determination of B-Carotene}

Beta-carotene will be determined using spectrophotometric method described by Pearson, [10].One (1 $\mathrm{ml}$ ) of the sample was dissolved with $10 \mathrm{ml}$ of acetone in a $50 \mathrm{ml}$ conical flask, allowed to stand for $20 \mathrm{mins}$ and shake gently at $4 \mathrm{mins}$ interval to extract the colour substance in the sample. About $10 \mathrm{ml}$ of water was added after agitation and allowed to settle. The upper layer was separated. The solution was cleared into a test tube; $5 \mathrm{ml}$ of hexane was added, allowed to settle in 2 layers. The layers were separated using a separating funnel. The uppers layer was used for $\beta$-carotene analysis. Then $2 \mathrm{ml}$ of the supernatant was pipetted into a curvet and read in the spectrophotometer (Janway-6300, England) at $453 \mathrm{~nm}$.

$\frac{\text { Absorbance of test }}{\text { Absorbance of standard }} \times \frac{\text { Concentration of standard }}{\text { Weight of sample }}$

\subsection{Vitamin C Content Determination}

Vitamin C content was determined by titration following the AOAC [9] protocol. Standard ascorbic acid solution (Sigma, USA) was made by dissolving $0.05 \mathrm{~g}$ of pure acid in $45 \mathrm{ml}$ of extraction solution in a volumetric flask and the solution was made up to the $50 \mathrm{ml}$ mark. The vitamin $\mathrm{C}$ extraction solution (5\% trichloroacetic acid) was made by dissolving $50 \mathrm{~g}$ of the pure acid in one litre of distilled water. Ten (10) $\mathrm{ml}$ of the sample was transferred into a volumetric flask. More extraction solution was added until the $100 \mathrm{ml}$ mark, the contents mixed thoroughly and filtered immediately. Aliquots $(10 \mathrm{ml})$ of the extract were titrated against standard 2,6 dichlorophenol indophenols (DCPIP) obtained by dissolving $0.05 \mathrm{~g}$ of DCPIP in $100 \mathrm{ml}$ distilled water and standardized by titration against $2 \mathrm{ml}$ of standard ascorbic acid. An equivalent amount of the extraction solution taken as the blank was titrated against standard DCPIP and correction for it made in the final titre. The ascorbic acid content of the sample was calculated using the formula;

Vitamin C content (mg/100g DM)- Titre x Ve x V1 x 100 x 100

$$
\text { V2 x S x } 1000 \text { x Y }
$$

Where $\mathrm{Ve}=$ vitamin $\mathrm{C}$ equivalent of $1 \mathrm{ml}$ of DCPIP $(\mathrm{mg} / \mathrm{ml})$

$\mathrm{V} 1=$ total extract volume $(\mathrm{ml}), \mathrm{V} 2=$ titrated extract volume $(\mathrm{ml}), \mathrm{S}=$ sample weigh

$\mathrm{Y}=$ sample dry matter $(\%)$

\subsection{Determination of Antioxidant Activity}

The antioxidant activity of the moringa leaf extracts where determined using the free radical scavenging activity and the ferric reducing antioxidant power. 


\subsection{Determination of Free Radical Scavenging Activity}

The DPPH free radical scavenging activity of aqueous extracts of M. oleifera was determined according to the method reported by Brand-Williams et al., [11] with slight modification. The stock solution of the radical, prepared by dissolving $24 \mathrm{mg}$ DPPH in $100 \mathrm{ml}$ methanol, was kept in a refrigerator until further use. The working solution of the radical was prepared by diluting the DPPH stock solution with methanol to obtain an absorbance of about $0.98( \pm 0.02)$ at $517 \mathrm{~nm}$.

In a test tube, $3 \mathrm{ml}$ DPPH working solution was mixed with $100 \mu \mathrm{l}$ plant extract $(1 \mathrm{mg} / \mathrm{ml})$. The absorbance was measured with a UV-visible spectrophotometer (Janway-6300, England) at $517 \mathrm{~nm}$ for a period of 30mins. The percent antioxidant or radical scavenging activity was calculated using the following formula:

$\%$ Antioxidant activity $=[(\mathrm{Ac}-\mathrm{As}) / \mathrm{Ac}] \times 100$

Where, Ac and As are the absorbance of control and sample, respectively. The control contained 100 $\mu \mathrm{l}$ methanols in place of the plant sample. The procedure was repeated at different DPPH concentrations $(4,6,8$ and $10 \mathrm{mg} / \mathrm{ml})$.

\subsection{Measurement of the Reducing Power of the Extracts}

The reducing power of the aqueous sample extracts was determined according to the method of Yen and Chen [12]. The extracts $(2 \mathrm{ml})$ were mixed with an equal volume of $0.2 \mathrm{M}$ phosphate buffer, pH6.6 and $1 \%$ potassium ferricyanide. The mixture was incubated at $50 \mathrm{oC}$ for $20 \mathrm{mins}$ after which an equal volume of $1 \%$ trichloroacetic acid (TCA) was added to the mixture, which was then centrifuged (Gallenkamp, England) at 5,000rpm for 10mins. The upper layer of the solution was mixed with distilled water and $0.1 \% \mathrm{FeCl} 3$ in a ratio of $1: 1: 2$ and the absorbance of the upper layer were measured with UV-visible spectrophotometer (Janway-6300, England) at 700nm, at varying concentrations and using ascorbic acid as control. Increased absorbance of the reaction mixture indicated increased reducing power. Total reducing power was expressed as absorbance units per total phenolics per gram of sample. The procedure was repeated at different FRAP concentrations $(4,6,8$ and $10 \mathrm{mg} / \mathrm{ml})$.

\section{RESUlTS AND DisCUSSIONS}

The effect of boiling time on the proximate composition of the moringa leaf extracts is shown in table 1. Boiling time brought about a significant $(p<0.05)$ variation in the proximate properties of the moringa leaf extracts. The ash content of the extracts appreciated significantly $(p<0.05)$ with the boiling time, the content ranged from $0.485 \%$ for MLE 0 to $1.455 \%$ for MLE ${ }_{15}$, the increase in the ash content could attribute to evapouration of water with subsequent concentration of constituents. Udousoro and Etuk, [13] had similar results in their research work on fresh Telfairia occcidentalis. The ash content of a food or substance tells us the mineral content of that substance and minerals are nutrients that are needed in the body for body metabolism and tissue formations.

The moisture content of the extracts reduced significantly $(\mathrm{p}<0.05)$ as the boiling time increases; the moisture content ranged from $84.915 \%$ for $\mathrm{MLE}_{15}$ to $97.580 \%$ for $\mathrm{MLE}_{0}$, the decrease in the moisture content of the extracts is as a result of the heating process which brings about evaporation in the extracts and also the high moisture content is attributed to the extraction method (aqueous extraction) of the moringa leaf extracts. Navarro-Gozalez et al., [14] observed same trends of values for Tropaelum majus and Spilanthes oleracea which has a high moisture value be declines as the heating time progresses and Asogwa et al., [15] observed same on boiling Moringa leaf.

The protein content of the moringa leaf extract increased significantly $(p<0.05)$ with the boiling time, the proteins content ranged from $0.630 \%$ for $\mathrm{MLE}_{0}$ and $1.395 \%$ for $\mathrm{MLE}_{15}$, the increase in the protein level would be as a result of the concentrating of the extracts due to heating, similar increase was also seen in the work done by Bakari et al., [16] on Cactus cladode extracts, the protein content will beneficial to the body even though it's in small amount.

Table1. Proximate Compositions of the Moringa Leaf Extracts (\%)

\begin{tabular}{|c|c|c|c|c|}
\hline Samples & MLE $_{0}$ & MLE $_{5}$ & MLE $_{10}$ & MLE $_{15}$ \\
\hline ASH & $0.485 \pm 0.01^{\mathrm{a}}$ & $0.485 \pm 0.01^{\mathrm{a}}$ & $0.960 \pm 0.04^{\mathrm{b}}$ & $1.455 \pm 0.02^{\mathrm{c}}$ \\
\hline MOISTURE & $97.580 \pm 0.01^{\mathrm{c}}$ & $96.925 \pm 0.23^{\mathrm{c}}$ & $90.185 \pm 0.13^{\mathrm{b}}$ & $84.915 \pm 0.53^{\mathrm{a}}$ \\
\hline PROTEIN & $0.630 \pm 0.01^{\mathrm{a}}$ & $0.640 \pm 0.01^{\mathrm{a}}$ & $0.900 \pm 0.08^{\mathrm{b}}$ & $1.395 \pm 0.08^{\mathrm{c}}$ \\
\hline
\end{tabular}




\begin{tabular}{|c|c|c|c|c|}
\hline \multicolumn{5}{|c|}{} \\
\hline FAT & $0.835 \pm 0.01^{\mathrm{a}}$ & $0.865 \pm 0.01^{\mathrm{a}}$ & $2.825 \pm 0.06^{\mathrm{b}}$ & $2.955 \pm 0.02^{\mathrm{c}}$ \\
\hline CRUDE FIBRE & ND & ND & ND & ND \\
\hline CARBOHDRATE & $0.470 \pm 0.03^{\mathrm{a}}$ & $1.085 \pm 0.23^{\mathrm{a}}$ & $5.130 \pm 0.07^{\mathrm{b}}$ & $9.280 \pm 0.49^{\mathrm{c}}$ \\
\hline
\end{tabular}

Values in the same row bearing different superscript are significantly difference at $\mathrm{p}<0.05$; data are expressed as means of duplicates \pm standard deviation (SD)

$\mathrm{ND}=$ Nothing Detected $. \mathrm{MLE}_{0}=$ Unboiled Moringa Leaf Extracts, MLE $_{5}=$ Five Minutes Boiled Moringa Leaf Extracts, MLE $_{10}=$ Ten Minutes Boiled Moringa Leaf Extracts, MLE $15=$ Fifteen Minutes Boiled Moringa Leaf Extracts.

Table2. Vitamin Composition of Moringa Leaf Extracts

\begin{tabular}{|c|c|c|}
\hline SAMPLES & $\begin{array}{c}\text { B-CAROTENE (mg/100g) } \\
\text { (Pro-Vitamin A) }\end{array}$ & VITAMIN C (mg/100g) \\
\hline MLE $_{0}$ & $1.447 \pm 0.31^{\mathrm{a}}$ & $32.970 \pm 0.83^{\mathrm{c}}$ \\
\hline MLE $_{5}$ & $6.600 \pm 0.02^{\mathrm{b}}$ & $29.385 \pm 1.01^{\mathrm{b}}$ \\
\hline MLE $_{10}$ & $7.668 \pm 0.02^{\mathrm{c}}$ & $21.990 \pm 1.32^{\mathrm{a}}$ \\
\hline MLE $_{15}$ & $10.346 \pm 0.06^{\mathrm{d}}$ & $20.850 \pm 0.1^{\mathrm{a}}$ \\
\hline
\end{tabular}

Values in the same column bearing different superscript are significantly difference at $\mathrm{p}<0.05$; data are expressed as means of duplicates \pm standard deviation (SD)

$\mathrm{MLE}_{0}=$ Unboiled Moringa Leaf Extracts, $\mathrm{MLE}_{5}=$ Five Minutes Boiled Moringa Leaf Extracts.

$\mathrm{MLE}_{10}=$ Ten Minutes Boiled Moringa Leaf Extracts, MLE $15=$ Fifteen Minutes Boiled Moringa Leaf Extracts.

The fat content of the extracts increases with the boiling time significantly $(\mathrm{p}<0.05)$, the contents are $0.835 \%$ for $\mathrm{MLE}_{0}$ to $2.955 \%$ for $\mathrm{MLE}_{15}$, the increase in the fat content of the leaf extract is as a result concentrating of the extracts and also that moringa is slightly an oil containing plant, related trends was noticed in the work done by Sunday et al., [17] on fresh Curcuma longa extract its lipid contents also increased with heating, the fat content of the extract is highly beneficial because the oil found in Moringa oleifera is an essential oil.

The fibre content of the moringa leaf extracts was significantly $(p<0.05)$, at increasing boiling time, but the result of the analysis shows that nothing was detected for all the extract samples, this result could be attributed to high moisture content and the filtration process.

The carbohydrate content of the extracts increased significantly $(p<0.05)$ with boiling time, the carbohydrate contents of the extracts ranges from $0.470 \%$ for $\mathrm{MLE}_{0}$ to $9.280 \%$ for $\mathrm{MLE}_{15}$, the increase in the content is as a result that the extract is carbohydrate based and the concentrating of the extracts which was brought by the boiling of the extracts. Adeniyan et al., [18] observed the similar increase in the carbohydrate content of Sesamum indicum.

The effect of boiling time on the vitamin content of the moringa leaf extracts was seen in Table 2. The boiling time of the extracts brought about significant $(p<0.05)$ deviations in the vitamin contents of the moringa leaf extract. The $\beta$-carotene content of the extract samples increased significantly $(\mathrm{p}<0.05)$ with boiling time, the $\beta$-carotene content of the samples increased from $1.447 \mathrm{mg} / 100 \mathrm{~g}$ for $\mathrm{MLE}_{0}$ to $10.346 \mathrm{mg} / 100 \mathrm{~g}$ for $\mathrm{MLE}_{15}$, the increase in the $\beta$-carotene content of the extracts is attributed to the concentration of the extracts during boiling and also mild heating process disrupts the cell walls of the plant extracts thereby releasing the $\beta$-carotene content of the samples and Anjum, [19] had a similar trends of results on his work on spinach and lettuce

The vitamin $\mathrm{C}$ content of the leaf extracts decreases significantly $(\mathrm{p}<0.05)$ as the boiling time increases, the vitamin $\mathrm{C}$ content of the extracts ranged from $20.850 \mathrm{mg} / 100 \mathrm{~g}$ for $\mathrm{MLE}_{15}$ to 32.970 $\mathrm{mg} / 100 \mathrm{~g}$ for $\mathrm{MLE}_{0}$, the reduction in the vitamin C content of the extracts was because Vitamin $\mathrm{C}$ is a water soluble vitamins and that it is heat labile. Some of the vitamin $\mathrm{C}$ would have leached out during the washing process. The work done by Igwemmar et al., [20] on some vegetables portrays similar trends of vitamin $\mathrm{C}$ content decrease when heat processed.

The effect of boiling time on the DPPH (2,2, Diphenyl -1- picrythdrazyl) activity of the moringa leaf extracts at varying DPPH concentrations $(4,6,8$ and $10 \mathrm{mg} / \mathrm{ml})$ is presented in Figure 1. Both the DPPH concentration and the boiling time led to significant $(\mathrm{p}<0.05)$ increases in the DPPH activity of the moringa leaf extracts. For instance at $4 \mathrm{mg} / \mathrm{ml}$, the DPPH activity increased from $15.140 \%$ for $\mathrm{MLE}_{0}$ to $35.490 \%$ for $\mathrm{MLE}_{15}$, at $6 \mathrm{mg} / \mathrm{ml}$ it increase from $17.690 \%$ for $\mathrm{MLE}_{0}$ to $45.465 \%$ for 
$\mathrm{MLE}_{15}$, at $8 \mathrm{mg} / \mathrm{ml}$ it was from $18.265 \%$ for $\mathrm{MLE}_{0}$ to $47.905 \%$ for $\mathrm{MLE}_{15}$ and at $10 \mathrm{mg} / \mathrm{ml}$ it was $28.150 \%$ for $\mathrm{MLE}_{0}$ to $54.035 \%$ for $\mathrm{MLE}_{15}$. The increase in the DPPH activity of the moringa leaf extracts came as expected because of the results got from the flavonoid and phenol of the moringa leaf extracts Obiajulu et al, [21], so their increase is as a result of the high content of the phenolics compounds in the leaf. Phenolic compounds are known to exhibit good antioxidants. Shukla et al., [22] also observed an increase in the DPPH activity of Dracaena reflexa leaves, when subjected to heating over time and also similar trends was noticed in the investigation of the DPPH activity of Reinwardtia indica leaves extract [23]. The increase in the activity for both DPPH and FRAP are highly beneficial to human health because they are great indicators that moringa leaf extracts is a rich source of natural antioxidants and can be used for the reduction of the high rate of oxidative stress related illnesses like cancer, obesity, diabetes and host of others.

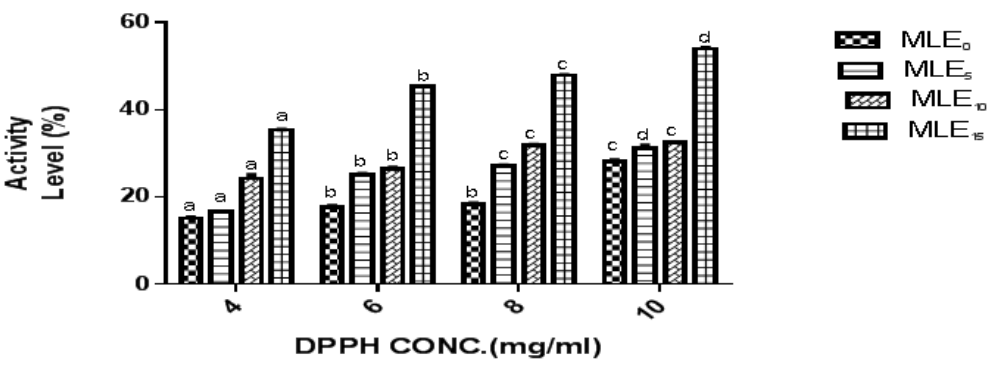

Figure1. Effect of Boiling Time on the DPPH Activity (\%) of Moringa Leaf Extracts at varying DPPH Concentration

Bars of the same pattern bearing different superscript are significantly difference at $\mathrm{p}<0.05$; data are expressed in mean of duplicates \pm standard deviation (SD)

$\mathrm{MLE}_{0}=$ Unboiled Moringa Leaf Extracts, $\mathrm{MLE}_{5}=$ Five Minutes Boiled Moringa Leaf Extracts,

$M_{10}=$ Ten Minutes Boiled Moringa Leaf Extracts, $M_{15}=$ Fifteen Minutes Boiled Moringa Leaf Extracts.

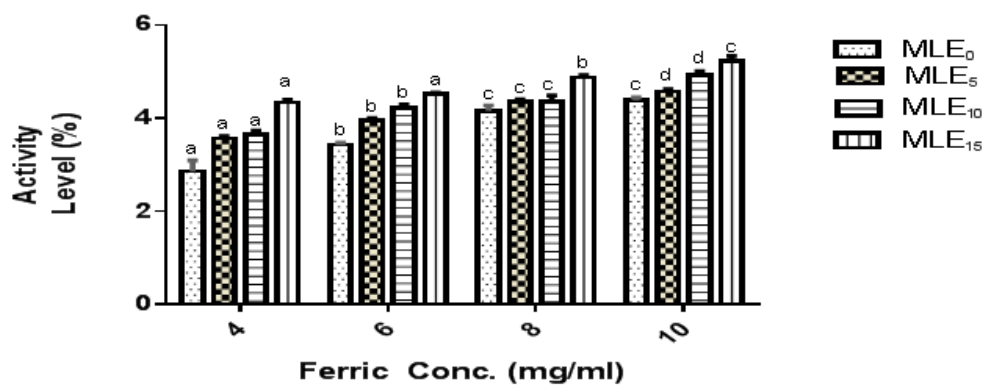

Figure2. The Effect of Boiling Time on the Ferric Reducing Antioxidant Power of the Moringa Leaf Extracts at Different FRAP Concentration

Bars of the same pattern bearing different superscript are significantly difference at $\mathrm{p}<0.05$; data are expressed in mean of duplicates \pm standard deviation (SD)

$\mathrm{MLE}_{0}=$ Unboiled Moringa Leaf Extracts, $\mathrm{MLE}_{5}=$ Five Minutes Boiled Moringa Leaf Extracts.

$\mathrm{MLE}_{10}=$ Ten Minutes Boiled Moringa Leaf Extracts, $\mathrm{MLE}_{15}=$ Fifteen Minutes Boiled Moringa Leaf Extracts .

The effect of boiling time on the FRAP (Ferric Reducing Antioxidant Power) of moringa leaf extracts at varying FRAP reagent concentrations $(4,6,8$ and $10 \mathrm{mg} / \mathrm{ml})$ is shown in figure 2 . Both the FRAP concentration and the boiling time increment had led to significant $(\mathrm{p}<0.05)$ increase in FRAP potentials of the moringa leaf extracts. For example at $4 \mathrm{mg} / \mathrm{ml}$ the FRAP activity appreciated from $2.868 \%$ for $\mathrm{MLE}_{0}$ to $4.335 \%$ for $\mathrm{MLE}_{15}$, at $6 \mathrm{mg} / \mathrm{ml}$ it move from $3.430 \%$ for $\mathrm{MLE}_{0}$ to $4.520 \%$ for $\mathrm{MLE}_{15}$, at $8 \mathrm{mg} / \mathrm{ml}$ it was from $4.165 \%$ for MLE $\mathrm{M}_{0}$ to $4.875 \%$ for $\mathrm{MLE}_{15}$ and at $10 \mathrm{mg} / \mathrm{ml}$ it was 4.390 $\%$ for $\mathrm{MLE}_{0}$ to $5.225 \%$ for $\mathrm{MLE}_{15}$. The increase in the FRAP activity of the moringa leaf extracts did not come as surprise bearing in mind the results of the flavonoid and phenol of the moringa leaf extracts [21], so their increase is as a result of the rich sources of the phenolics compounds in the moringa leaf. A similar trend was observed in the investigation done by Shukla et al., [22] on Dracaena reflexa leaves and also that of Abdul-rasheed et al., [24] on the extracts some commonly used spices in India when heated over time. 


\section{CONCLUSION}

The research showed that the moringa leaf extracts contain phenol and flavonoids in appreciable quantities [21]. Boiling time also caused significant increase in all the proximate composition of the leaf extracts except for moisture that decreased and crude fibre which was not detected. Results of vitamin analysis showed that while vitamin $\mathrm{C}$ content of the extracts decreased with boiling time, Provitamin A content increased as boiling progressed.

The antioxidants properties determined using DPPH and FRAP at various concentrations; showed high antioxidant activities. The antioxidant activities increased with both the boiling time and concentration of the DPPH and FRAP reagents.

This research has shown that boiled moringa leaf extracts possessed higher antioxidant activity than the raw sample. This implies that boiled leaf extracts would posses' higher health promoting potentials than the raw extracts. It is recommended therefore that for moringa leaf extracts should be boiled for at least $15 \mathrm{mins}$ for optimum antioxidant activity.

\section{REFERENCES}

[1] Olson, Mark E (2010). Moringaceae Martinov; Drumstick Tree Family; In: Flora of North America, North of Mexico, Volume 7: Magnoliophyta: Dilleniidae, Part 2. Oxford University Press. p. 168. ISBN 0195318226.

[2] Leone A, Spada A, Battezzati A, Schiraldi A, Aristil J, Bertoli S (2015). "Cultivation, Genetic, Ethnopharmacology, Phytochemistry and Pharmacology of Moringaoleifera Leaves: An Overview". International Journal of Molecular Science, 16(6):12791-835.

[3] Peter, K.V., (2008). Underutilized and Underexploited Horticultural Crops, Vol. 4 . New India Publishing. p. 112. ISBN 81-89422-90-1.

[4] Kosolo N. Josephine, Gabriel S. Bimenya, Lonzy Ojok, Joseph Ochieng and Jasper W. Ogwal-Okeng, (2010), Phytochemicals and uses of Moringa oleifera leaves in Ugandan rural communities, Journal of Medicinal Plants Research, 4(9):753-757.

[5] Newton G.L., Rawat, M., La-Clair, J.J., Jothivasan, V.K., Budiarto, T., Hamilton, C.J., Claiborne, A., Helmann, J.D. and Fahey, R.C., (2009). "Bacillithiol is an Antioxidant Thiol Produced in Bacilli". Journal of Nature Chemical Biology. 5 (9): 625-627.

[6] Hamid, M.; Leibfritz, D.; Moncol, J.; Cronin, M.T.D.; Mazur, M.; Telser, J.(2010) Free radicals and antioxidants in normal physiological functions and human disease. International Journal of Biochemistry and Cell Biolology,39: 44-84.

[7] Teresa, S.J., Katz A, Wang, Y., Eck, P., Kwon, O., Lee, J.H., Chen, S., Corpe, C., Dutta, A.,Dutta, S.K.,and Levine, M. ( 2011). "Vitamin C as an antioxidant: evaluation of its role in disease prevention". Journal of the American College of Nutrition. 22 (1): 18-35.

[8] Grumezescu, N., Alexandru, J., Mihai, B., Holban, K. and Alina M., (2018). Food Processing for Increased Quality and Consumption. Academic Press. p. 430. ISBN 9780128114995

[9] AOAC (2010). Official Method of Analysis, 17th edition. Association of Official Analysis Chemist, Washington DC.20044.

[10] Pearson, B. (2010). Chemical analysis of foods. 7th ed, London: Churchill. Wingston, Edinburgh.

[11] Brand-williams, W., Carelier, M. E. and Beset, C. (1995), Use of Free Radical Method to Available Antioxidant Activity, Lebanese Wiss Technology, 30:609-615.

[12] Yen, G. C. and Chen, H.Y. (1995). Antioxidant Activity of various Tea Extracts in Relation to their Antimanagenicity, Journal of Agricultural and Food Chemistry 46:849-854.

[13] Udousoro, I. and Etuk, B., (2012), Effects of Heating Temperature and Time on the Nutrients and Antinutrients Composition of Telfairia occidentalis (Hook F.) International Journal of Modern Chemistry, www.ModernScientificPress.com/Journals/IJMChem.aspx,

[14] Navarro-Gozalez, J., Onyeike, E. N.; Ihugba, A. C. And George, C. (2015) Influence of heat processing on the nutrient composition of vegetable leaves consumed in Nigeria. Journal of Plant Foods and Human Nutrition, 58: 1-11.

[15] Asogwa, I. S., Onweluzo, J. C. and Omah, E. (2018) Effect of boiling time and sun drying on the nutrient composition of Moringa oleifera leaf powder, International Journal of Food and Nutritional Science, 7(1)

[16] Bakari, S., Daoud, A., Felhi, S., Smaoui, S., Gharsallah, N., and Kadri, A., (2017), Proximate Analysis, Mineral Composition, Phytochemical Contents, Antioxidant and Antimicrobial Activities and GC-MS 
Investigation of Various Solvent Extracts of Cactus cladode, Food Science and Technology (Campinas), 37(2):46.

[17] Sunday, R.M., Onyeka, C.F., Afolayan, M. P., Onwatogwu, J. and Oshagbemi, B. O., (2016) Phytochemical Properties and Effect of Temperature on Proximate and Mineral Composition of Curcuma longa Linn. Rhizomes Ethanolic Extract, International Journal of Biochemistry Research \& Review 15(4): $1-6$.

[18] Adeniyan O.O.1, Ibukun E.O., Ogunbolude Y.1 and Eseigbe M.I., (2013), Effect of boiling on the nutritional composition and antioxidant properties of Beniseed (Sesamum indicum L.)Food Science and Quality Management, 11:39. ISSN 2224-6088.

[19] Anjum, F., Ali Khan, B., Noreen, N., Masood, T. and Faisal, S., (2008). Effect of boiling and storage on Beta-carotene content of different vegetables, Pakistan Journal of life and Social Sciences. 6(1):63-67

[20] Igwemmar, N.C., Kolawole, S.A and Imran, A.I., (2013) Effect Of Heating On Vitamin C Content Of Some Selected Vegetables. International Journal of Scientific \& Technology Research :2(11):54. ISSN 2277-8616

[21] Obiajulu, E.I., Asogwa, I.S and Omah, E.C., The effects of boiling time on the phytochemical content of moringa leaf extract, Macmillan Press, Enugu (2019). (conference proceeding style)

[22] Shukla A., Vats S., and Shukla R.K., (2013) Preliminary Phytochemical Screening, Antibacterial and Nitric Oxide Scavenging Activities of Reinwardtia indica Leaves Extract. International Journal of Pharmaceutical Technology and Research, 5:1670-8.

[23] Shukla, A., Swati V., and Shukla, R. K., (2015), Phytochemical Screening, Proximate Analysis and Antioxidant Activity of Dracaena reflexa Lam. Leaves, Indian Journal of Pharmaceutical Science; 77(5): 640-644.

[24] Abdul-rasheed M.D., Veenavani M., and Prameela D. Y., (2013), A study on antioxidant activity of some commonly used spices in India, International Journal of Life Science Biotechnology and Pharmaceutical Research, Hyderabad, India, 2:4. ISSN 2250-3137.

Citation: Obiajulu, Emmanuel Ifeanyi, Asogwa, Ifeyinwa Sabina, "Effects of Boiling Time on the Antioxidant Activity of Moringa Leaf Extract", International Journal of Research Studies in Biosciences, 8(3), pp. 18-26. DOI: http://dx.doi.org/10.20431/2349-0365.0803003

Copyright: (C) 2020 Authors, This is an open-access article distributed under the terms of the Creative Commons Attribution License, which permits unrestricted use, distribution, and reproduction in any medium, provided the original author and source are credited. 